\title{
Effect of time of extraction on the biocompatibility of endodontic sealers with primary human fibroblasts
}

\section{Miriam Zaccaro Scelza ${ }^{(a)}$ Jeffrey Coil(b) \\ Gutemberg Gomes Alves ${ }^{(c)}$}

(a) Laboratory of Experimental Cell Culture, Department of Endodontics, Univ Federal Fluminense - UFF, Niteroi, RJ, Brazil.

(b) Department of Oral Biological and Medical Sciences, University of British Columbia, Vancouver, BC, Canada.

(c) Molecular and Cell Biology Department, Institute of Biology, Univ Federal Fluminense - UFF, Niteroi, RJ, Niteroi, Brazil.
Declaration of Interests: The authors certify that they have no commercial or associative interest that represents a conflict of interest in connection with the manuscript.

Corresponding Author: Miriam Zaccaro Scelza

E-mail: scelza@terra.com.br

Submitted: Mar 07, 2012

Accepted for publication: Jul 03, 2012

Last revision: Jul 13, 2012

\begin{abstract}
The aim of this work was to evaluate the effects of different times of extraction on the cytotoxicity of six representatives of different root canal sealer groups-Real Seal SE, AH Plus, GuttaFlow, Sealapex, Roth 801, and ThermaSeal Plus-with human gingival fibroblasts. The materials were prepared according to manufacturers' specifications, and were incubated in culture medium (DMEM) at $37^{\circ} \mathrm{C}$ for $1,7,14,21$, and 28 days, with daily washing, to simulate periodontal ligament clearance. Human fibroblasts were exposed to the final extracts at 24 hours, and cell viability was determined by MTT assay, with exposure to unconditioned DMEM as a negative control. Statistical analysis comparing cytotoxicities at each exposure time was performed by ANOVA with Scheffé adjustment for multiple comparisons at a 95\% confidence level. Results indicated that GuttaFlow was significantly less cytotoxic than all other sealers $(\mathrm{p}<0.05)$ at 1 day of extraction. After 7 days of extraction, cell viability for GuttaFlow was significantly increased as compared with that of all groups except sealer AH Plus. At day 14, cytotoxicity of Sealapex was significantly higher than that of all other sealers $(\mathrm{p}<0.05)$. At days 21 and 28, there were no significant differences in cytotoxicity among sealer groups. All materials presented some level of cytotoxicity to fibroblasts, while GuttaFlow was the least cytotoxic sealer tested. However, the cytotoxicity of all materials seemed to decrease similarly in a time-dependent manner.
\end{abstract}

Descriptors: Materials Testing; Endodontics; In vitro.

\section{Introduction}

A wide range of root canal sealers is presently available, based on different chemical compositions such as epoxy resins, calcium hydroxides, polyvinylsiloxane-based materials, and zinc oxide-eugenol, presenting diverse physical properties, functionalities, and practical features.

Zinc oxide-eugenol formulations have been among the most widely used sealers in the last 80 years. ${ }^{1}$ Representatives of this group, such as Roth 801, may include $\mathrm{Bi}$ and $\mathrm{Ba}$ salts for $\mathrm{x}$-ray contrast and present some antibacterial activity, as well as better wettability of dentin and gutta-percha surfaces than other sealers. ${ }^{2}$

Resin-based sealers also have decades of successful use in Endodontics. Epoxy-based sealers, such as AH Plus, exhibit very low shrinkage rates during setting, as well as long-term dimensional stability, and po- 
lymerization without formation of formaldehyde. ${ }^{3}$ Thermaseal Plus is another example of an epoxyresin sealer, which has been demonstrated as presenting significantly less leakage than other sealer groups. ${ }^{4}$ Other important resin-based materials are the thermoplastic synthetic urethane dimethacrylate-based root-filling materials such as RealSeal or Epiphany, ${ }^{5}$ described as presenting increased resistance to fractures of root-filled teeth. ${ }^{6}$

Calcium hydroxide materials represent yet another important family of sealers. Materials from this group, such as Sealapex and Apexit, are expected to present bioactivity, even though with complex setting reaction and lack of physical sturdiness. ${ }^{1}$

The stability and adhesive properties of silicone led to the production of sealers such as GuttaFlow, a combination of nanometer-sized silver particles, gutta-percha powder, and polydimethylsiloxane, developed with the intention of overcoming the disadvantages of the warm gutta-percha obturation technique. ${ }^{7}$ The slight expansion of these materials during setting is conjectured to result in an improved apical seal of the root canal system. ${ }^{8}$

Regardless of their composition, root canal sealers should be biocompatible and present satisfactory physico-chemical properties. International standards ${ }^{9}$ advise that the assessment of biocompatibility is critical prior to the clinical use of rootfilling materials. In this context, in vitro cytotoxicity assays are helpful for the initial evaluation of biocompatibility of dental materials, allowing for simple, reproducible, and controlled results. Moreover, the use of human primary cells in such tests is considered a gold standard in toxicology, due to a higher correlation with expected clinical results, as compared with animal-originating and or tumoral/ transformed lineages.

Another factor possibly affecting the results of indirect cytotoxicity tests is the time of extraction in culture media prior to cell exposure. Even though myriad investigators have already studied the cytocompatibility of representatives of all major groups of endodontic sealers, very different methodologies have been used, with variations in cell type, and times of extraction ranging from a few hours to several weeks after setting, making it very difficult to compare the biocompatibilities of different groups of sealers. Camps and About ${ }^{10}$ also demonstrated that standard methodologies tend to overestimate the cytotoxicity of sealers, leading to results conflicting with the clinical performance of these materials. In this manner, it is possible that conflicting results and very differing cytotoxicity profiles found for diverse groups of materials in several studies on cytotoxicity might be related to differences on the methodological approach, including choice of cell type, time of extraction, or periodic removal of exposure media.

Therefore, the aim of this work was to evaluate and compare the cytotoxicities of representatives of major groups of endodontic sealers (RealSeal SE, AH Plus, GuttaFlow, Sealapex, Roth Root 801, and ThermaSeal Plus) to primary human gingival fibroblasts (HGF), in the same methodological approach and with different times of extraction (from 1 to 28 days), with constant change of medium of exposure, to simulate, to some extent, the clearance of the periodontal ligament.

\section{Methodology Preparation of extracts}

Table 1 presents the compositions of the six tested sealers. Each material $(0.1 \mathrm{~g})$ was prepared according to the manufacturer's instructions, and fragments with diameters of less than $0.5 \mathrm{~cm}$ were immediately immersed in $1 \mathrm{~mL}$ of serum-free DMEM $^{9}$ (GIBCO Invitrogen, Grand Island, USA), and incubated at $37^{\circ} \mathrm{C}$ for $1,7,14,21$, or 28 days. Extracts were renewed daily to simulate periodontal ligament clearance. ${ }^{10,11}$ The final extracts were collected and filtered through a $0.22-\mu \mathrm{m}$ filter (Mil$\operatorname{lex}^{\mathrm{TM}}$ GP, Millipore, Cork, Ireland).

\section{Cell culture}

Human gingival fibroblasts (HGF) were obtained from the Laboratory of the Department of Oral Biological and Medical Sciences of The University of British Columbia (Vancouver, Canada). Cell cultures between $6^{\text {th }}$ and $9^{\text {th }}$ passages, cultivated in DMEM containing $10 \%$ fetal bovine serum (GIBCO Invitrogen, Grand Island, USA) and 1\% antibiotic and antimicotic, at $37^{\circ} \mathrm{C} / 5 \% \mathrm{CO}_{2}$, were seeded 


\begin{tabular}{|c|c|c|c|}
\hline \multirow{7}{*}{$\begin{array}{r}\text { Table } 1 \text { - Composition of the } \\
\text { endodontic sealers } \\
\text { investigated }\end{array}$} & Product and manufacturer & Component $\mathrm{A}$ & Component B \\
\hline & $\begin{array}{l}\text { GuttaFlow } \\
\text { (Coltène-Whaledent, } \\
\text { Langenau, Germany) }\end{array}$ & GuttaFlow primer: heptane & $\begin{array}{l}\text { GuttaFlow: } \\
\text { polydimethylsiloxane, paraffin } \\
\text { oil, platinum catalyst, } \\
\text { zirconium dioxide, nano-silver, } \\
\text { gutta-percha powder }\end{array}$ \\
\hline & $\begin{array}{l}\text { Real Seal SE } \\
\text { (SybronEndo, Orange, USA) }\end{array}$ & $\begin{array}{l}\text { BisGMA, ethoxylated BisGMA, } \\
\text { UDMA, hydrophilic monomers } \\
\text { Fillers: calcium hydroxide, barium } \\
\text { sulfate, barium glass, silica }\end{array}$ & \\
\hline & $\begin{array}{l}\text { AH Plus } \\
\text { (Dentsply/Maillefer, } \\
\text { Konstanz, Germany) }\end{array}$ & $\begin{array}{l}\text { Epoxy resins, calcium tungstate, } \\
\text { zirconium oxide, aerosil, iron oxide }\end{array}$ & $\begin{array}{l}\text { Adamantane amine, N,N- } \\
\text { dibenzyl-5-oxanonane, TCD- } \\
\text { diamine, calcium tungstate, } \\
\text { zirconium oxide, aerosil }\end{array}$ \\
\hline & $\begin{array}{l}\text { Thermaseal Plus (Dentsply/ } \\
\text { Maillefer, Konstanz, } \\
\text { Germany) }\end{array}$ & $\begin{array}{l}\text { Epoxy resin, calcium tungstate, } \\
\text { zirconium oxide, aerosil, iron oxide }\end{array}$ & $\begin{array}{l}\text { Adamantane amine, } \mathrm{N}, \mathrm{N} \text { - } \\
\text { dibenzyl-5-oxanonane- } \\
\text { diamine-1,9, TCD-diamine, } \\
\text { calcium tungstate, zirconium } \\
\text { oxide, aerosil, silicone oil }\end{array}$ \\
\hline & $\begin{array}{l}\text { Sealapex } \\
\text { (Kerr, Romulus, USA) }\end{array}$ & $\begin{array}{l}\text { Calcium oxide, bismuth trioxide, } \\
\text { zinc oxide, sub-micron silica, } \\
\text { zinc stearate, titanium dioxide, } \\
\text { tricalcium phosphate }\end{array}$ & $\begin{array}{l}\text { Blend, ethyl toluene } \\
\text { sulfonamide, poly (methylene } \\
\text { methyl salicylate) resin, } \\
\text { isobutyl salicylate }\end{array}$ \\
\hline & $\begin{array}{l}\text { Roth Root } 801 \\
\text { (Roth International, Chicago, } \\
\text { USA) }\end{array}$ & $\begin{array}{l}\text { Zinc oxide, hydrogen resin, } \\
\text { bismuth subcarbonate, barium } \\
\text { sulfate, sodium borate }\end{array}$ & Eugenol, sweet almond oil \\
\hline
\end{tabular}

at a density of $3 \times 10^{4}$ cells $\mathrm{mL}^{-1}$ in wells of a 96 well plate and incubated for $24 \mathrm{~h}$ at $37^{\circ} \mathrm{C} / 5 \% \mathrm{CO}_{2}$. Cells were exposed by replacement of the medium of each well with $200 \mu \mathrm{L}$ of one of the extracts previously described, followed by incubation for $24 \mathrm{~h}$, and MTT assay. The experiments were performed twice and run in triplicate.

\section{Cytotoxicity assay}

The effects of the different sealers on HGF cells were evaluated by 3-[4,5-dimethylthiazol-2-yl]-2,5diphenyl tetrazolium bromide) MTT assay (Sigma, St. Louis, USA). A tetrazolium reagent is reduced by mitochondrial dehydrogenases into blue formazan molecules, which can be measured by spectrophotometry. ${ }^{12}$ The amount of formazan produced is directly proportional to the total viable cell number. After each experimental period, the medium was replaced by MTT solution $(5 \mathrm{mg} / \mathrm{mL})$ diluted 1:10 in PBS $(100 \mu \mathrm{L} /$ well $)$ and incubated for $3 \mathrm{~h}$ at $37^{\circ} \mathrm{C}$. The supernatant was removed, and the formazan crystals were dissolved with a solubilizing agent. Optical density (OD) was measured with a micro- plate reader (Model 3550, Bio-Rad, Richmond, USA) at $595 \mathrm{~nm}$. Cell viability was expressed as a percentage of the negative control, i.e., HGF cells exposed to unconditioned medium.

\section{Statistical analysis}

Statistical analysis was performed by Analysis of Variance (ANOVA) for each experimental period, followed by Scheffé test adjustment for multiple comparisons at a $95 \%$ confidence level.

\section{Results}

Figure 1 shows the cytotoxicities of sealers at different extraction times. At day 1, the number of viable cells exposed to GuttaFlow was significantly different from all other groups $(\mathrm{p}<0.05)$. At seven days, the number of viable cells in the GuttaFlow group remained significantly different $(\mathrm{p}<0.05)$ from most tested sealers, except for AH Plus. Also, unlike the first day of extraction, there were significant differences $(\mathrm{p}<0.05)$ between several pairs of endodontic sealers other than GuttaFlow. At day 14 , the cell viability for GuttaFlow was significantly 


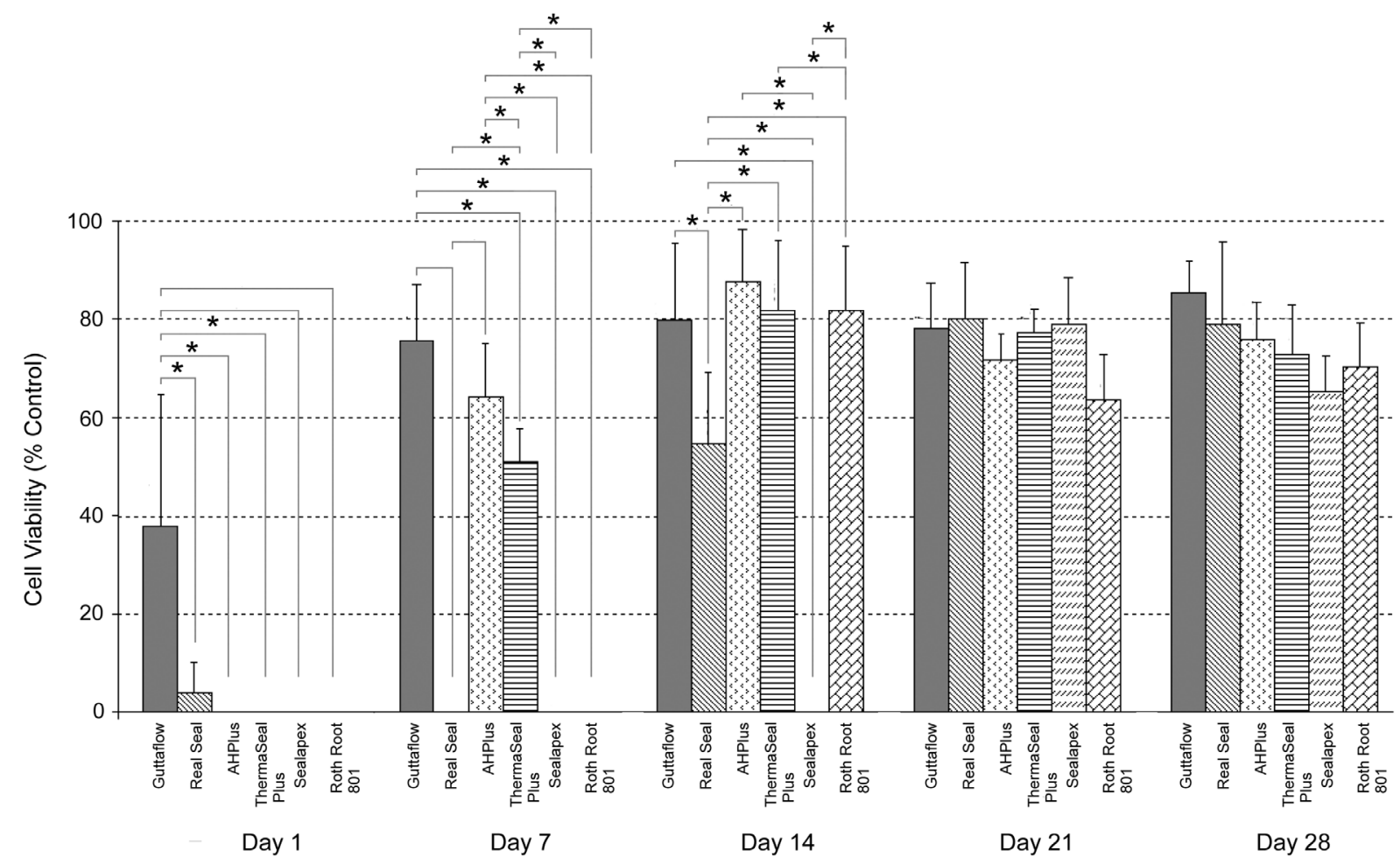

Figure 1 - Cell viability expressed as a percentage of control mean viable cells ( \pm standard deviation), after each extraction time $(n=6)$. Asterisks indicate significant differences in the intraday analysis (ANOVA followed by Scheffé test adjustment, $p<0.05$ ).

different $(p<0.05)$ only from Sealapex. There were significant differences between the following pairs of sealers $(\mathrm{p}<0.05)$ :

- RealSeal and AH Plus,

- RealSeal and Thermaseal Plus,

- RealSeal and Sealapex,

- AH Plus and Sealapex,

- Thermaseal and Sealapex, and

- Sealapex and Roth.

However, at 21 and 28 days, there were no significant differences among the tested materials $(\mathrm{p}>0.05)$.

\section{Discussion}

The cytotoxicities of endodontic sealers may be affected by several factors, such as composition, setting characteristics, stability, and area between the root canal filling and adjacent soft and hard tissues. ${ }^{13,14}$

In the present study, an in vitro model was chosen for the evaluation of biocompatibility, due to the advantages of using standardized growth medium composition, a defined incubator milieu, and sterile working conditions, allowing for an accurate quantitative and qualitative evaluation of the results. ${ }^{9}$ Also, the extracts used in this study were undiluted at day 1 , since a pilot study demonstrated that cytotoxicity increased concomitantly with extract concentration (data not shown). The major feature of the present methodology, however, is the assaying of a wide range of times of extraction after setting, with a daily washing of the material, in an attempt to simulate, to some degree, the clearance to which filling materials may be exposed with the internal circulation of body fluids, such as blood and extracellular matrix from the root canal system. ${ }^{10,11}$ Such clearance might decrease the inherent cytotoxicity of the representatives of all groups of endodontic sealers tested here.

Special care must be taken in the selection of the cell type or lineage for the evaluation of a given biomaterial, since they must behave reliably, similarly to the affected tissue in vivo. AL-Nazhan 
and Spangberg ${ }^{15}$ demonstrated that periodontal ligament cells, from either established permanent lines or primary cultures, are adequate for in vitro methods for the testing of dental filling materials. Moreover, Willershausen et al. ${ }^{16}$ have demonstrated that diploid human fibroblasts of gingival and nasal origin present improved sensitivity when compared with transformed epithelial tumor cells. This may be a problem commonly faced in studies with transformed cells, which are usually aneuploid. The expected desirable similarity of primary cell culture with in vivo tissue responses, and the recognition of human gingival fibroblasts as an adequate model for the early detection of possible cytotoxic effects of root canal filling materials, ${ }^{16-19}$ led to the choice of these cells in the present methodology.

GuttaFlow consists of a very fine gutta-percha powder, making it the first flowable sealer/guttapercha combination at room temperature. ${ }^{20}$ Even though the literature has described an increase on this material's cytotoxicity with time after mixing, which could be attributed to the release of silver particles, ${ }^{8}$ in the present work GuttaFlow was less cytotoxic than all other sealers tested, at most exposure times.

It was found that Real Seal or Epiphany exhibited more cytotoxicity at days 1 and 7 than at other time intervals. Other studies have corroborated these findings, showing that Epiphany or Real Seal was cytotoxic at the 24-hour time interval. , $11,21,22^{2}$ However, in contrast to our results, other authors ${ }^{23}$ found that the cytotoxicity of this material increases with time. It is important to note, however, that the longest time used in other works was considerably lower than those used in the present methodology. As described previously, initial cytotoxicity could be explained by the monomer constituents of the dentine-bonding agents Bis-GMA and urethane dimethacrylate (UDMA), as well as by the precursor Bis-MA. Additionally, cytotoxicity could be attributed to the triethyleneglycol dimethacrylate (TEGDMA) component. ${ }^{8,11,21-23}$

In contrast to the present results, Merdad et al. ${ }^{13}$ demonstrated that freshly mixed Epiphany $(0 \mathrm{~h})$ showed a moderate cytotoxic effect, undetectable at $24 \mathrm{~h}$. The probable reason for this discrepancy is the different methodologies and cells used, since the authors used Millipore filters in direct or indirect contact with HeLa cells. The present research ascertained the cytotoxicity of RealSeal without Resilon, despite the possibility of overfilling due to the large surface of contact between the resin and the surrounding tissue.

In the present study, AH Plus showed cytotoxic effects at 1 day, in agreement with previous studies. ${ }^{8,18,24,25}$ Also, in accordance with Miletic et al. ${ }^{25}$ and Al-Hiyasat et al., ${ }^{26}$ cytotoxicity was reduced after 7 days, while the present work also showed a decrease by 14, 21, and 28 days. In contrast, Azar et al. ${ }^{27}$ using the neutral red assay, demonstrated that $\mathrm{AH}$ Plus induced significant cytotoxicity at 1 and $4 \mathrm{~h}$, but no toxicity was detectable after $4 \mathrm{~h}$. Huang et al. ${ }^{28}$ demonstrated that $\mathrm{AH}$ Plus at $24 \mathrm{~h}$ was cytotoxic to astrocytes in a dose-dependent manner. They showed that this sealer was also genotoxic, with an inhibitory dose $\left(\mathrm{ID}_{50}\right)$ of $0.04 \mathrm{mg} / \mathrm{mL}$. This short-time cytotoxicity of AH Plus has been attributed to the release of formaldehyde, in spite of its manufacturer's claim that this filling sealer is formaldehyde-free. ${ }^{24}$ The formaldehyde release is likely due to the epoxy resin reaction with amines in the initial setting reaction.

The present research has shown that Sealapex was strongly cytotoxic at days 1,7 , and 14 . Previous investigations have reported similar cytotoxic results with Sealapex and other cell types, to which it was more toxic at day 1 , when compared with Real Seal (Epiphany) and AH Plus. ${ }^{10,17}$ However, Chang et al., ${ }^{29}$ showed only a moderate cytotoxicity to periodontal ligament fibroblasts at 3 and $18 \mathrm{~h}$. Regardless of time, this cytotoxicity probably resulted from components/additives such as polymethylene methyl salicylate resin and isobutyl salicylate (Table 1) present in Sealapex. ${ }^{30}$

Roth Root 801 proved to be a cytotoxic material at day 1 , in agreement with the results of Key et al. ${ }^{17}$ In contrast, Willershausen et al., ${ }^{16}$ using the prostaglandin release assay in gingival fibroblast cultures, found a relatively low cytotoxic effect of Super-EBA, another reinforced zinc oxide-eugenol material, at longer times, while the eugenol-based Roth Root 801 still demonstrated a high cytotoxic 
effect by day 7 (Figure 1). This phenomenon possibly correlates with the results of Schwarze et al., ${ }^{21}$ who described, in a study with 3T3 and HPL cells, that endomethasone strongly inhibited mitochondrial activity during the first $5 \mathrm{~h}$, very likely due to the release of the cytotoxic substance eugenol.

In spite of the fact that this research may differ from true clinical conditions, the results obtained from the current in vitro cytotoxic studies might provide a reliable view of the biological effects and clinical potential of these materials.

\section{Conclusion}

All tested materials were cytotoxic for human gingival fibroblasts, while GuttaFlow, a silicon-

\section{References}

1. Orstavik D. Materials used for root canal obturation: technical, biological and clinical testing. Endod Topics. 2005 Aug;12:25-38.

2. Kontakiotis EG, Tzanetakis GN, Loizides AL. A comparative study of contact angles of four different root canal sealers. J Endod. 2007 Mar;33(3):299-302.

3. Carvalho-Junior JR, Correr-Sobrinho L, Correr AB, Sinhoreti MA, Consani S, et al. Solubility and dimensional change after setting of root canal sealers: a proposal for smaller dimensions of test samples. J Endod. 2007 Sep;33(9):1110-6.

4. Britto LR, Borer RE, Vertucci FJ, Haddix JE, Gordan VV. Comparison of the apical seal obtained by a dual-cure resin based cement or an epoxy resin sealer with or without the use of an acidic primer. J Endod. 2002 Oct;28(10):721-3.

5. Pameijer $\mathrm{CH}$, Zmener O. Resin materials for root canal obturation. Dent Clin North Am. 2010 Apr;54(2):325-44.

6. Hemalatha H, Sandeep M, Kulkarni S, Yakub SS. Evaluation of fracture resistance in simulated immature teeth using Resilon and Ribbond as root reinforcements-an in vitro study. Dent Traumatol. 2009 Aug;25(4):433-8.

7. Wu D, Tang Z, Zhang G, Liu W. The sealing ability of a new silicone-based root canal filling material (GuttaFlow): an in vitro study using the percentage of gutta-percha-filled area. Dent Mater J. 2011 Nov;30(5):569-75.

8. Bouillaguet S, Wataha JC, Tay FR, Brackett MG, Lockwood $\mathrm{PE}$. Initial in vitro biological response to contemporary endodontic sealers. J Endod. 2006 Oct;32(10):989-92.

9. International Standards Organization (ISO). ISO 7405:2008. Dentistry - Preclinical evaluation of biocompatibility of medical devices used in dentistry - Test methods for dental materials. Genève: International Standards Organization (ISO); 2008. based material, was the least cytotoxic at most experimental times studied. However, since the present model simulated the constant clearance of the periodontal ligament, the cytotoxicity of endodontic sealers seemed to decrease in a time-dependent manner.

\section{Acknowledgements}

The authors acknowledge the financial assistance from CAPES (Proc. \# 2993-06-6), which enabled Miriam Z. Scelza to hold a Visiting Associate Professorship at the University of British Columbia, Faculty of Dentistry. This research was supported by the FAPERJ (No. e-26/110.909/2009) and the Canadian Academy of Endodontics.

10. Camps J, About I. Cytotoxicity testing of endodontic sealers: a new method. J Endod. 2003 Sep;29(9):583-6.

11. Susini G, About I, Tran-Hung L, Camps J. Cytotoxicity of Epiphany and Resilon with a root model. Int Endod J. 2006 Dec;39(12):940-4.

12. Sumantran VN. Cellular chemosensitivity assays: an overview. Methods Mol Biol. 2011 Jul;731:219-36.

13. Merdad K, Pascon AE, Kulkarni G, Santerre P, Friedman S. Short-term cytotoxicity assessment of components of the Epiphany resin-percha obturating system by indirect and direct contact Millipore filter assays. J Endod. 2007 Jan;33(1):24-7.

14. Mittal M, Chandra S, Chandra S. Comparative tissue toxicity evaluation of four endodontic sealers. J Endod. 1995 Dec;21(12):622-4.

15. Al-Nazhan S, Spangberg L. Morphological cell changes due to chemical toxicity of a dental material: an electron microscopic study on human periodontal ligament fibroblasts and L929 cells. J Endod. 1990 Mar;16(3):129-34.

16. Willershausen B, Marroquin BB, Schafer D, Schulze R. Cytotoxicity of root canal filling materials to three different human cell lines. J Endod. 2000 Dec;26(12):703-7.

17. Key JE, Rahemtulla FG, Eleazer PD. Cytotoxicity of a new root canal filling material on human gingival fibroblasts. J Endod. 2006 Aug;32(8):756-8.

18. Miletic I, Devcic N, Anic I, Borcic J, Karlovic Z, Osmak M. The cytotoxicity of RoekoSeal and AH Plus compared during different setting periods. J Endod. 2005 Apr;31(4):307-9.

19. Khashaba RM, Chutkan NB, Borke JL. Comparative study of biocompatibility of newly developed calcium phosphatebased root canal sealers on fibroblasts derived from primary human gingiva and a mouse L929 cell line. Int Endod J. 2009 Aug;42(8):711-8. 
20. Eldeniz AU, Orstavik D. A laboratory assessment of coronal bacterial leakage in root canals filled with new and conventional sealers. Int Endod J. 2009 Apr;42(4):303-12.

21. Schwarze T, Leyhausen G, Geurtsen W. Long-term cytocompatibility of various endodontic sealers using a new root canal model. J Endod. 2002 Nov;28(11):749-53.

22. Baraba A, Zeljezic D, Kopjar N, Mladinic M, Anic I, Miletic I. Evaluation of cytotoxic and genotoxic effects of two resin-based root-canal sealers and their components on human leucocytes in vitro. Int Endod J. 2011 Jul;44(7):652-61.

23. Karapinar-Kazandag M, Bayrak OF, Yalvac ME, Ersev H, Tanalp J, Sahin F, et al. Cytotoxicity of 5 endodontic sealers on L929 cell line and human dental pulp cells. Int Endod J. $2011 \mathrm{Jul} ; 44(7): 626-34$.

24. Cohen BI, Pagnillo MK, Musikant BL, Deutsch AS. An in vitro study of the cytotoxicity of two root canal sealers. J Endod. 2000 Apr;26(4):228-9.

25. Miletic I, Jukic S, Anic I, Zeljezic D, Garaj-Vrhovac V, Osmak M. Examination of cytotoxicity and mutagenicity of AH26 and AH Plus sealers. Int Endod J. 2003 May;36(5):330-5.
26. Al-Hiyasat AS, Tayyar M, Darmani H. Cytotoxicity evaluation of various resin based root canal sealers. Int Endod J. 2010 Feb;43(2):148-53.

27. Azar NG, Heidari M, Bahrami ZS, Shokri F. In vitro cytotoxicity of a new epoxy resin root canal sealer. J Endod. 2000 Aug;26(8):462-5.

28. Huang TH, Yang JJ, Li H, Kao CT. The biocompatibility evaluation of epoxy resin-based root canal sealers in vitro. Biomaterials. 2002 Jan;23(1):77-83.

29. Chang MC, Lin LD, Chen YJ, Tsai YL, Cheng YA, Kuo CS, et al. Comparative cytotoxicity of five root canal sealers on cultured human periodontal ligament fibroblasts. Int Endod J. 2010 Mar;43(3):251-7.

30. Lapczynski A, Jones L, McGinty D, Bhatia SP, Letizia CS, Api AM. Fragrance material review on methyl salicylate. Food Chem Toxicol. 2007 Jul;45 Suppl 1:S428-52. 